\title{
From Emollients to Biologicals: Targeting Atopic Dermatitis
}

\author{
Lorenzo Salvati ${ }^{D}$, Lorenzo Cosmi * and Francesco Annunziato \\ Department of Experimental and Clinical Medicine, University of Florence, 50134 Florence, Italy; \\ lorenzo.salvati@unifi.it (L.S.); francesco.annunziato@unifi.it (F.A.) \\ * Correspondence: lorenzo.cosmi@unifi.it
}

Citation: Salvati, L.; Cosmi, L.; Annunziato, F. From Emollients to Biologicals: Targeting Atopic Dermatitis. Int. J. Mol. Sci. 2021, 22, 10381. https://doi.org/10.3390/ ijms221910381

Academic Editor: Genji Imokawa

Received: 1 September 2021

Accepted: 24 September 2021

Published: 26 September 2021

Publisher's Note: MDPI stays neutral with regard to jurisdictional claims in published maps and institutional affiliations.

Copyright: (c) 2021 by the authors. Licensee MDPI, Basel, Switzerland. This article is an open access article distributed under the terms and conditions of the Creative Commons Attribution (CC BY) license (https:// creativecommons.org/licenses/by/ $4.0 /)$.
Abstract: Atopic dermatitis (AD) is the most common chronic inflammatory skin disease and significantly impacts patients' lives, particularly in its severe forms. AD clinical presentation varies over the course of the disease, throughout different age groups, and across ethnicities. AD is characterized by a spectrum of clinical phenotypes as well as endotypes. Starting from the current description of $\mathrm{AD}$ pathogenesis, this review explores the rationale of approved AD therapies from emollients to biologicals and introduces novel promising drugs.

Keywords: atopic dermatitis; therapy; skin; type 2 inflammation; emollients; barrier repair therapy; dupilumab; nemolizumab; JAK-inhibitors

\section{Introduction}

"It is true the longest drought will end in rain."-Robert Frost (from On Looking Up By Chance At The Constellations, 1928).

Atopic dermatitis (AD) treatment is nowadays moving towards a real paradigm shift, especially for patients affected by severe AD. In fact, the advent of biological therapies is changing the management and course of severe $A D$, giving patients a treatment option that is safer than traditional systemic therapies and with excellent clinical results. Notwithstanding emollients are still the mainstay of treatment, the systemic therapeutic approach to $\mathrm{AD}$ has changed in recent years moving from traditional systemic therapies to monoclonal antibodies and more recently introducing small molecules. However, none of the advances that we are witnessing today would have been possible without the study of the pathogenic mechanisms that underlie this inflammatory skin disease.

\section{Atopic Dermatitis: Molecular and Clinical Features}

AD is a chronic inflammatory cutaneous disease with prevalence rates up to $20 \%$ in children and $10 \%$ in adults [1-3]. Multifactorial pathogenesis, characterized by a complex interplay of epidermal barrier dysfunction, host genetics, environmental factors, and immune perturbations, underlies $\operatorname{AD}[1,4]$.

\subsection{Genetic Factors}

Genetic factors include loss-of-function (LoF) mutations in the gene encoding filaggrin (FLG) [5]. Filaggrin is a major structural protein, whose monomers aggregate and align keratin bundles with an important role in ensuring the mechanical strength and integrity of the stratum corneum, and whose metabolites contribute to forming the natural moisturizing factor [6]. Between $10 \%$ and $40 \%$ of patients with atopic dermatitis present with LoF mutations of the FLG gene and have a disease phenotype characterized by early-onset, higher severity, face and hands involvement, palmar hyperlinearity, increased susceptibility to Staphylococcal infections, asthma and food allergy [7].

\subsection{Type 2 Response and Beyond}

Historically, experimental models which are based on the atopy patch test showed a biphasic pathogenetic process in AD: in the acute phase, AD is a T helper (Th)2 cell- 
mediated disease, while a switch to Th1 cells promotes the chronic phase [8]. As a consequence of the epidermal barrier damage, antigens penetrate the skin, chemokines (CCL17, CCL22) are produced, and epithelial cytokines and alarmins (IL-25, IL-33 and TSLP) are released $[9,10]$. These events result in the activation of skin-resident innate lymphoid cells type 2 (ILC2) and polarize Th cells towards Th2 with the production of IL-4, IL-13 and IL-5 [11]. In addition to the activation of type 2 inflammation, pathways including Th1, Th17, and Th22 are also involved resulting in mixed inflammation [12-14]. Acute lesional AD skin shows mainly Th2 and Th22 immune responses. Persistence of Th2 and Th22 and sustained activation of Th1 and Th17 responses characterize chronic AD [15]. The chemokine CCL17, also known as thymus and activation-regulated chemokine (TARC), a chemoattractant of Th2 cells, correlates with AD clinical severity, at both the baseline and during therapy [16].

\subsection{Atopic-Type: Endotypes and Phenotypes in Atopic Dermatitis}

$\mathrm{AD}$ is a heterogeneous disease and includes a complex spectrum of endotypes according to the evaluation of molecular mechanisms in different groups of patients [17]. Differences are not only in relation to the stage of the disease, but the patient's age and ethnicity also contribute $[18,19]$. In fact, considering the clinical phenotype, the polarization of immune response and the barrier defect, differences exist between pediatric compared to the adult population. In infants, $\mathrm{AD}$ is generally acute and mainly involves the face and the extensor surfaces of the limbs, but also the trunk, while in young children, particularly flexural folds are involved. In children, AD lesional skin lacks Th1 infiltrate differently from adults [20,21]. The shared signature of AD across ages is Th2/Th22-skewed, yet the differential expression of specific Th2/Th22-related genes portrays heterogenetic agespecific molecular pathways. [22]. African American patients with AD display a dominant Th22 response, but not Th17, while Asian patients with AD are characterized by lower Th1 response [20].

$\mathrm{AD}$ is clinically characterized by acute (oozing, oedema, and erythema) and chronic (xerosis, and lichenification) lesions that can coexist during flares. As a result of pruritus, excoriations are often present. AD is classically a clinical diagnosis that is mainly based on morphology and distribution (both spatial and temporal) of skin lesions, disease course, coexisting conditions, personal and family history of atopy [4,23]. Several clinical phenotypes of AD have been described and are defined morphologically (nummular dermatitis, prurigo nodularis-like lesions, erythroderma, lichenified dermatitis, follicular/papular dermatitis and pompholyx [dyshidrosis]) and topographically (flexural or periorificial or occurring on the face, lips, eyelid, head and neck, hand and foot, or nipple) [23]. The atopic type is extremely complex. Immune cells involved in the inflammatory process and genetic alterations define endotypes that reflect disease presentation.

\section{Therapeutic Approach to Atopic Dermatitis}

To date, therapeutic management depends on the patient's age and disease severity (Figure 1). Management requires a multi-pronged approach aimed at controlling inflammation (anti-inflammatory), itching (anti-pruritic), bacterial superinfection (anti-bacterial) and skin barrier restoration (moisturizer). The treatment options for AD in adults and children are defined in practice clinical guidelines and summarized in Figure 1 [24-27]. The approach is stepwise in consideration of disease severity as assessed on the basis of the clinical features, extent and location of skin lesions, pruritus intensity, and sleep disturbance [26]. These characteristics can be measured with scores such as the SCORAD (SCOring Atopic Dermatitis) which classifies severe AD when it is above 50 [28]. The most common symptom in all patients with AD is itching. Already in the 1970s, before the pathogenesis was known in detail, it was written on Rook that the fundamental principle of AD therapy is to prevent scratching [29]. In the 1990s, Caputo and Ackerman wrote that "the single most important step in the management of atopic dermatitis is prevention of pruritus, without itching and scratching, there can be no atopic dermatitis" [30]. Today, 
we know that pruritus signaling pathways may be histamine-dependent or rely on other molecules such as IL-31 and are mediated by C and A $\delta$ fibers [1]. Pruritus in AD is only in part mediated by histamine [31-34]. Oral histamine $\mathrm{H} 1$ receptor antagonists are routinely used to try to relieve itching in AD patients, but there is currently no high-level evidence to support or refute that nonsedating antihistamines as monotherapy reduce pruritus in patients with AD [35-37]. When oral antihistamines are used in combination with other therapies, a better control of pruritus was observed compared to placebo [38,39]. Oral histamine $\mathrm{H} 4$ receptor antagonist (adriforant) showed clinical efficacy on inflammatory skin lesions in a phase 2 study but with a reduction in pruritus similar to placebo [40].

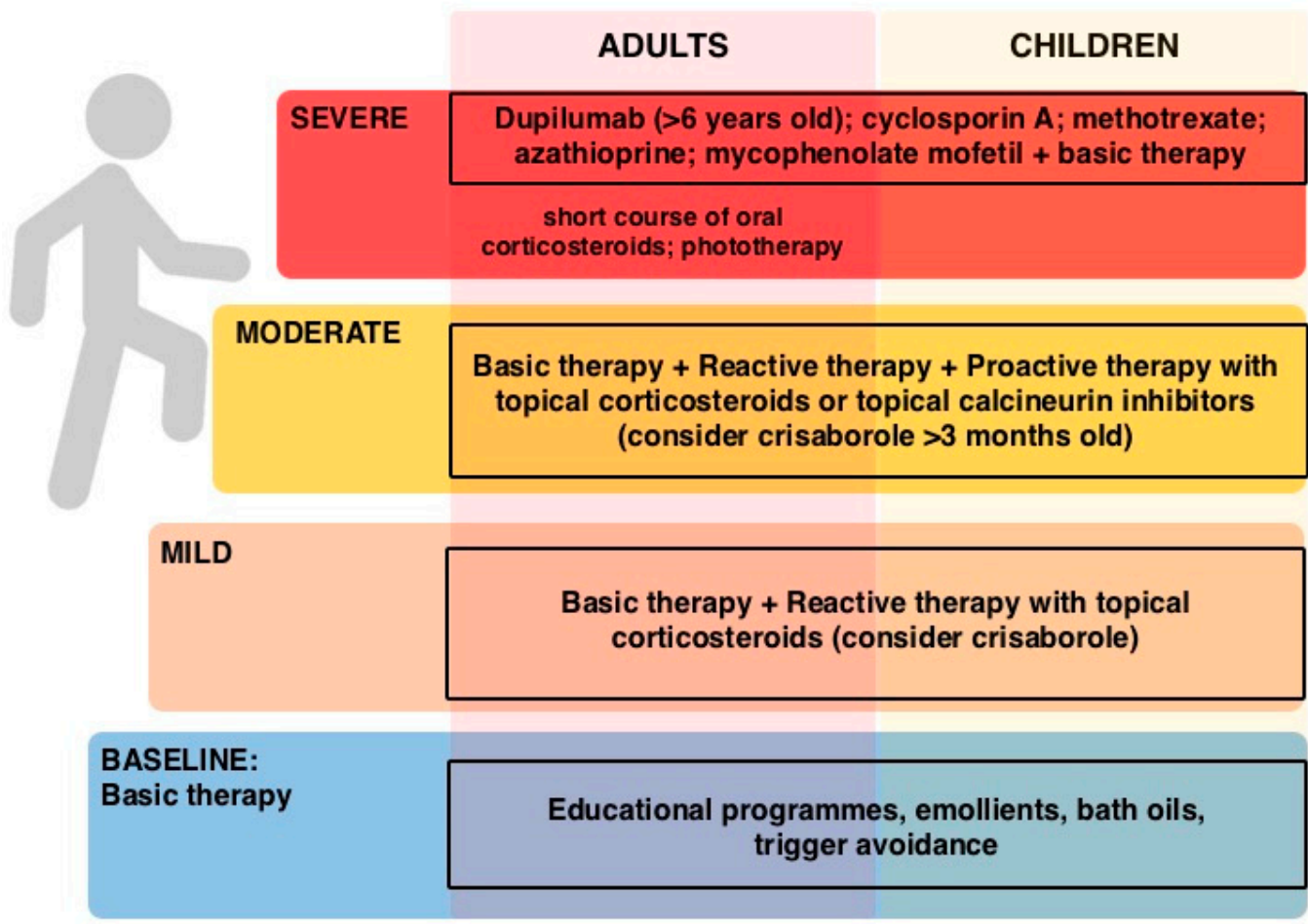

Add antiseptics / antibiotics in cases of superinfection

Figure 1. Atopic dermatitis therapeutic stepwise approach adapted from [24-26].

\subsection{Emollients}

The basic therapy, which may be sufficient in mild forms, is based on emollients whose action is aimed at restoring the integrity of the skin barrier, thus counteracting xerosis and reducing itching. The barrier damage in AD is determined by various factors (genetic and environmental) which in many ways contribute to enhance the protease activity at the level of the stratum corneum [41,42]. It becomes clear the reason why, as barrier repair therapy, emollients are the mainstay of AD treatment [43]. Regular daily use of the emollient extends the interval between relapses and attenuates the intensity of acute phases with steroid-sparing effect. The use of emollients from birth might contribute to the prevention of AD in children, as shown in prospective studies [44,45]. Emollients should be used liberally and frequently, at least $250 \mathrm{~g}$ per week in adults [24]. Composition of the product is important: emollients with fewer ingredients, fragrance-free and without known allergenic preservatives such as parabens, and preferably composed of physiological lipids (such as ceramides), should be preferred [46].

\subsection{Topical Immunesuppressants}

For topical therapy, anti-inflammatory drugs such as topical corticosteroids are used, particularly in acute phases [46-48]. Among the most powerful topical steroids, there is clobetasol propionate, but the most used in clinical practice are those of class III, generally used in single evening application (beclomethasone dipropionate, betamethasone dipro- 
pionate, betamethasone valerate, budesonide, desoximetasone, diflucortolone valerate, fluticasone propionate, methylprednisolone aceponate, mometasone furoate) $[24,46,49]$. The proactive therapy (e.g., twice a week application) is useful in maintaining disease control over time and reducing relapses [24,50]. Topical calcineurin inhibitors (pimecrolimus cream $1 \%$ and tacrolimus ointment $0.03 \%$ and $0.1 \%$ ) are also important anti-inflammatory drugs especially to be used in more sensitive skin areas (face, intertriginous sites, anogenital area) $[24,49]$. Proactive therapy with twice-weekly application of tacrolimus ointment may reduce relapses [51,52]. Effective sun protection is generally recommended [53].

\subsection{Topical Antibiotics}

Skin microbiome has a central role in topical therapy [54]. Up to $90 \%$ of AD patients present with Staphylococcus aureus skin colonization [55]. Bacterial communities antagonize each other and change over the course of the disease. Notably, skin flare-ups are species-specific and characterized by increased Staphylococcus aureus colonization in disease flares [56]. While topical therapy with fusidic acid or mupirocin is indicated in bacterial superinfection, Gram-negative bacterial lysates such as Vitreoscilla filiformis have been shown to improve AD reducing local inflammation [57,58]. It should also be noted that in patients with AD there is a higher prevalence of Staphylococcus aureus resistance to fusidic acid compared with healthy controls [59,60]. Moreover, Staphylococcus aureus isolates from children with AD differ in antimicrobial resistance profiles from those in non-atopic nasally colonized children [59,61].

\subsection{Traditional Systemic Therapy}

Traditional systemic therapy includes corticosteroids, cyclosporine A and other immunosuppressants [62]. Corticosteroids should be used for short-term treatment (up to 1 week) in the acute phase, preferentially in adults with severe AD [25]. The daily dose of systemic corticosteroids should be adjusted to and not exceed $0.5 \mathrm{mg} / \mathrm{kg} /$ day. Long-term use is not recommended [25]. Many randomized clinical trials (RCTs) indicate the efficacy of cyclosporine A versus placebo in $\mathrm{AD}$ [63]. Cyclosporine A can be used at $3-5 \mathrm{mg} / \mathrm{kg} / \mathrm{die}$ up to 2 years [25,64]. Azathioprine (2-3 mg/ $\mathrm{kg} /$ die), methotrexate (5-15 mg/week) and mycophenolate mofetil (2 g/day) can also be used in the management of severe AD [65-69].

\subsection{Monoclonal Antibodies}

The currently available treatments of AD are summarized in Table 1.

Table 1. Current available topical and systemic treatments in atopic dermatitis (as of September 2021).

\begin{tabular}{|c|c|}
\hline Treatment & Recommendation \\
\hline \multicolumn{2}{|c|}{ Topical treatments } \\
\hline Emollients & Use daily \\
\hline Topical corticosteroids & Short-term in the acute phase/proactive therapy \\
\hline Topical calcineurin inhibitors & Skin sensitive areas/proactive therapy \\
\hline Crisaborole & Mild-moderate AD \\
\hline Topical JAK-inhibitors & Delgocitinib approved in Japan \\
\hline \multicolumn{2}{|c|}{ Systemic treatments } \\
\hline Corticosteroids & Short-term in severe AD \\
\hline Cyclosporine A & Chronic severe AD \\
\hline $\begin{array}{l}\text { Azathioprine } \\
\text { Mycophenolate mofetil }\end{array}$ & If cyclosporine $\mathrm{A}$ is not effective or not indicated \\
\hline Methotrexate & Long-term maintenance \\
\hline Dunilumab & Moderate-severe AD (>12 years) \\
\hline Dupilumab & Severe $\mathrm{AD}(>6$ years) \\
\hline Oral JAK-inhibitors & Baricitinib in moderate-severe AD \\
\hline
\end{tabular}


In addition to emollients, traditional topical and systemic therapy, the armamentarium against $\mathrm{AD}$ is nowadays enriched by biological therapy approved in severe forms [70]. Monoclonal antibodies can directly target a cytokine or a receptor with the aim of modulating the inflammatory response [71,72].

Dupilumab is a fully human monoclonal antibody that binds to the IL-4R $\alpha$ chain [73]. This chain is found in the IL-4 receptor where it dimerizes with the $\gamma$ chain and in one of the two isoforms of the IL-13 receptor where it dimerizes with IL-13R $\alpha 1$ to form the IL-4/IL-13 receptor [74,75]. Consequently, dupilumab acts by blocking both IL-4 and IL-13 pathways and inhibiting the Th2 response which is central to the pathogenesis of AD. Dupilumab causes potent inhibition of Th2-associated chemokines (CCL17, CCL18, CCL22, and CCL26), decreases mRNA expression of hyperplasia-related genes (K16 and MKI67), and inhibits IL-17/IL-22-modulated genes (CXCL1, CXCL2, PI3, IL-23p19/IL-23A, and S100 genes) [76]. Dupilumab was the first monoclonal antibody approved for the treatment of moderate-to-severe AD in adults (in 2017), in adolescents aged 12 to 18 years (in 2019) and in children aged 6 to 11 years (in 2020) whose eczema is not adequately controlled by topical therapies, or when those therapies are not advisable [77-83]. Dupilumab should be combined with daily emollients and may be combined with topical corticosteroids as needed $[25,84]$. Data from the extension of phase 3 study (NCT01949311) to 76 weeks of treatment in adults demonstrated that efficacy was maintained over time and in terms of safety the most frequent adverse reaction was conjunctivitis in $10.7 \%$ of cases, followed by injection site reactions [85]. It is important to note, however, that in real life, as shown by the Italian DADReL study group, the incidence of conjunctivitis in AD patients treated with dupilumab tends to be higher than RCTs, approximately $40 \%$ [86]. A recent metaanalysis has confirmed that conjunctivitis is the most common adverse event, reported in $26.1 \%$ of patients [87]. The pathogenesis of these side effects is at present unknown [88-90]. In children, the treatment was well tolerated in the long term and the most frequent adverse reaction was nasopharyngitis [91]. Nonetheless, dupilumab has revolutionized the treatment of severe AD with significant improvement of symptoms and outcomes of patients, as confirmed in a recent systematic review including 1845 subjects $>12$ years treated 16 to 52 weeks, and yet is the only biological therapy approved in AD [92]. In the absence of well-powered head-to-head trials comparing all possible combinations of systemic immunomodulatory treatments, a systematic review and network meta-analysis demonstrated that dupilumab and cyclosporine may have better short-term effectiveness than methotrexate and azathioprine for the treatment of AD in adults [93]. Retrospective studies have shown longer drug survival for dupilumab compared to cyclosporine in severe AD [94,95].

Many further monoclonal antibodies are under study in AD, mainly targeting type 2 inflammation [96-98]. Tralokinumab and lebrikizumab are anti-IL-13 monoclonal antibodies that bind soluble IL-13 thus preventing IL-13R $\alpha$ heterodimerization with IL-4R $\alpha$ and consequent signaling via the IL-4R [96-98]. They both induced clinical improvement compared to placebo in $\mathrm{AD}$ patients: tralokinumab was superior to placebo at 16 weeks of treatment and it was well tolerated up to 52 weeks of treatment $[99,100]$. In a phase 2 study lebrikizumab was effective in reducing AD symptoms, even itching [101]. A phase 2a study of fezakinumab, anti-IL-22 monoclonal antibody, showed promising results compared to placebo, especially in patients with severe AD and particularly in those with high levels of IL-22 [102,103]. Tezepelumab, anti-TSLP monoclonal antibody, in combination with topical steroids did not show efficacy in adults with moderate to severe AD in a phase 2 study [104]. A proof-of-concept clinical trial of etokimab, anti-IL-33 monoclonal antibody showed rapid and sustained clinical benefit; a phase 2 study is under way (NCT03533751) [105].

Considering increased Th17 skewing in some AD endotypes, secukinumab, an anti-IL17A monoclonal antibody, was investigated in AD patients, but there was no significant improvement compared to placebo [106]. IL-17C antagonist (MOR106) in experimental models reduced skin inflammation $[107,108]$, but clinical studies (NCT03568071, NCT03864627, NCT03689829) were prematurely stopped for futility. 
Different results are observed, blocking the OX40-OX40L axis using GBR 830, a humanized monoclonal antibody against OX40 which is a costimulatory receptor expressed by activated $\mathrm{T}$ cells $[109,110]$. This approach resulted in improved clinical outcomes in a phase 2a study, and determined significant progressive reductions in Th1, Th2, Th17/Th22 mRNA expression in lesional AD skin [109]. KHK4083, a fully human anti-OX40 monoclonal antibody, was effective and safe in a phase 1 study of Japanese patients with moderate-to-severe AD [111]. A phase 2 study has just been completed (NCT03703102).

Being pruritus crucial in AD pathogenesis, diminished quality of life, and poor sleep, therapies aiming to block the itch-scratch cycle have been investigated. Nemolizumab, an anti-IL-31R $\alpha$ monoclonal antibody, was effective in controlling pruritus in AD patients [112-114]. A phase 3 study of 16 weeks duration demonstrated that in patients with moderate-to-severe $\mathrm{AD}$ the treatment with subcutaneous nemolizumab in addition to topical immunosuppressants resulted in a greater reduction in pruritus than placebo [115]. In patients treated with nemolizumab signs of eczema ameliorated, although that some patients reported worsening $\mathrm{AD}$ as an adverse event [115]. Studies evaluating the long-term efficacy and safety of nemolizumab in moderate-to-severe AD with pruritus are under way (NCT03989206).

\subsection{Other Therapies and Upcoming Therapies}

Crisaborole is a selective phosphodiesterase 4 (PDE4) inhibitor. In the topical $2 \%$ ointment formulation, it has been approved in 2016 for the treatment of mild to moderate $\mathrm{AD}$ in adults and pediatric patients from 2 years of age with $\leq 40 \%$ body surface area affected [116,117]. Crisaborole reduced inflammation-modulating Th2 and Th17/Th22 pathways in $\mathrm{AD}$ lesional skin and improved the barrier function reversing epidermal hyperplasia/proliferation [118].

A novel frontier in the treatment of $\mathrm{AD}$ is represented by JAK-inhibitors, small molecules that can be used both in the topical formulation thanks to their low molecular weight (about $300 \mathrm{kDa}$ lower than the skin barrier threshold), and in the systemic oral formulation $[119,120]$. These include delgocitinib, ruxolitinib, and tofacitinib as topic formulations, baricitinib, upadacitinib, abrocitinib, and gusacitinib as systemic drugs [121,122]. Delgocitinib (pan-JAK-inhibitor) in ointment formulation improved clinical signs and symptoms in children and in adults with AD and it was well tolerated [123-125]. In 2020 delgocitinib ointment was approved in Japan and it was the first topical JAK-inhibitor to be available [126]. Ruxolitinib (JAK1/JAK2 inhibitor) cream provided rapid and sustained improvements in symptoms and reduced pruritus in adults with AD [127,128]. Additionally, tofacitinib (JAK1/JAK3 inihbitor with limited effect on JAK2) ointment displayed good results in a phase 2a study [129]. Baricitinib, an oral selective JAK1/JAK2 inhibitor, improved the clinical signs and symptoms of moderate-to-severe AD in phase 3 studies and was effective and safe in the long term [130-133].

Treatment with upadacitinib or abrocitinib, oral selective JAK-1 inhibitors, resulted in significant clinical benefit in moderate-to-severe $\mathrm{AD}$ patients and was well tolerated [134-138]. In addition, gusacitinib a dual JAK-SYK inhibitor showed strong efficacy with rapid onset of action and reduced systemic inflammation in moderate-tosevere AD $[139,140]$.

\section{Conclusions}

$\mathrm{AD}$ is a complex heterogeneous disease as shown by the broad range of disease phenotypes and endotypes; thus, the therapeutic approach must be personalized for the single patient and endotype-driven. Treatment personalization should be based on an integrated approach including characteristics of the patient and the disease. The main factors that should be considered are age, ethnicity, gender (e.g., pregnancy and lactation), morphology and localization of skin lesions, the severity of disease in terms of both body surface area involved and intensity of symptoms (especially pruritus), duration of disease, frequency of $\mathrm{AD}$ relapses, response to previous $\mathrm{AD}$ treatments, coexisting 
conditions (e.g., mucosal atopy, immunodeficiency, etc.), possible concomitant therapies, and impact on patient's quality of life. The future prospect of personalized therapeutic options in $\mathrm{AD}$ will be the real-life use of validated $\mathrm{AD}$-specific biomarkers both in the selection/stratification and monitoring of $\mathrm{AD}$ patients. Old and new treatments of $\mathrm{AD}$ target molecular mechanisms fundamental in disease pathogenesis (Figure 2). Over the last few years, biological therapies and JAK-inhibitors have rapidly and promisingly expanded the armamentarium against $\mathrm{AD}$, so that the end of the drought does not seem so far.

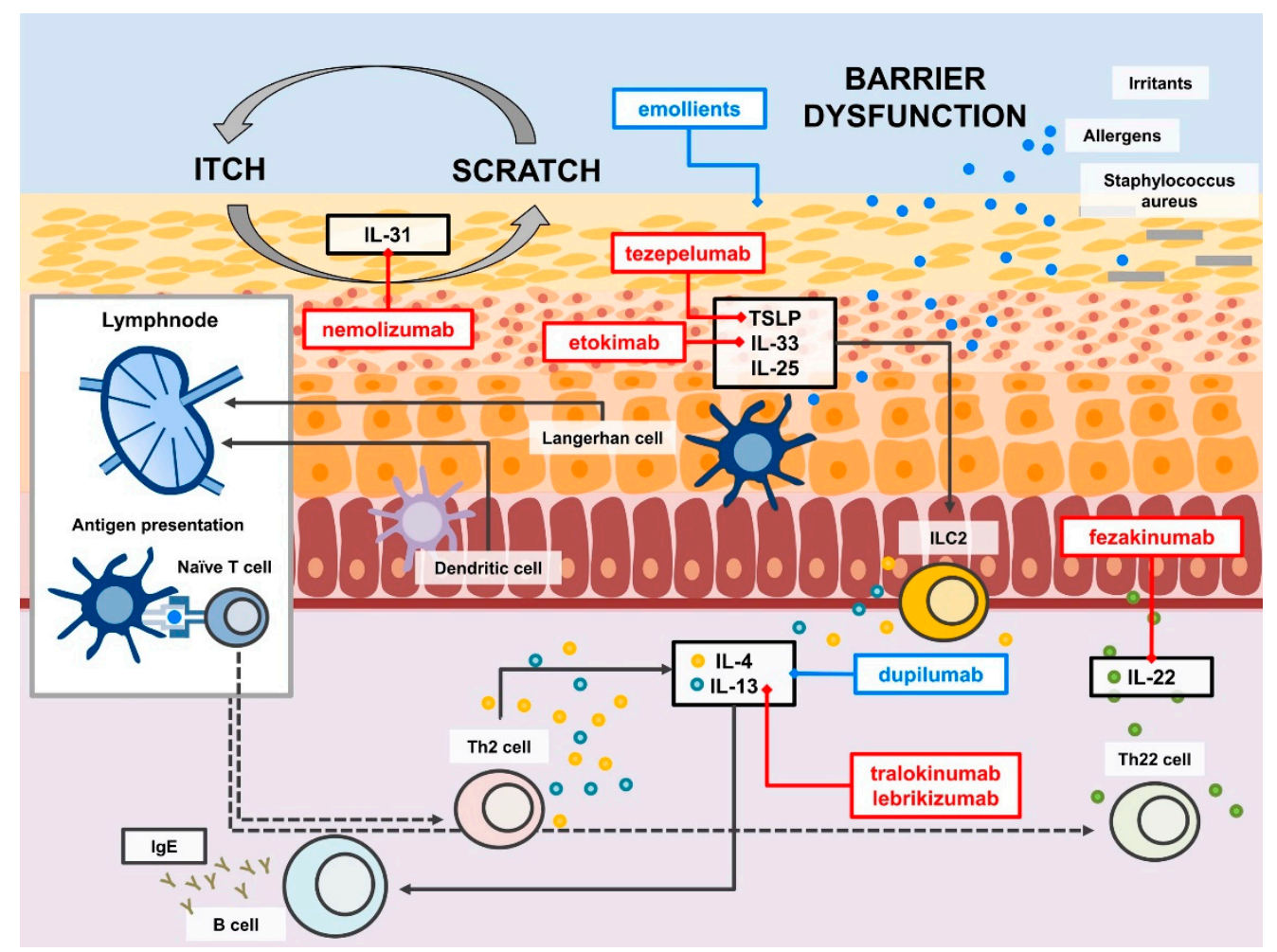

Figure 2. Main molecular pathways in atopic dermatitis targeted by emollients and biologicals. Approved available treatments are in blue boxes.

Author Contributions: L.S., L.C. and F.A. conceptualized and wrote the manuscript. All authors have read and agreed to the published version of the manuscript.

Funding: This research received no external funding.

Conflicts of Interest: The authors declare no conflict of interest.

\section{References}

1. Weidinger, S.; Beck, L.A.; Bieber, T.; Kabashima, K.; Irvine, A.D. Atopic dermatitis. Nat. Rev. Dis. Primers 2018, 4, 1. [CrossRef]

2. Bylund, S.; von Kobyletzki, L.B.; Svalstedt, M.; Svensson, Å. Prevalence and Incidence of Atopic Dermatitis: A Systematic Review. Acta Derm. Venereol. 2020, 100, adv00160. [CrossRef]

3. Drucker, A.M. Atopic dermatitis: Burden of illness, quality of life, and associated complications. Allergy Asthma Proc. 2017, 38, 3-8. [CrossRef] [PubMed]

4. Ständer, S. Atopic Dermatitis. N. Engl. J. Med. 2021, 384, 1136-1143. [CrossRef] [PubMed]

5. Løset, M.; Brown, S.J.; Saunes, M.; Hveem, K. Genetics of Atopic Dermatitis: From DNA Sequence to Clinical Relevance. Dermatology 2019, 235, 355-364. [CrossRef] [PubMed]

6. Irvine, A.D.; McLean, W.H.; Leung, D.Y. Filaggrin mutations associated with skin and allergic diseases. N. Engl. J. Med. 2011, 365, 1315-1327. [CrossRef]

7. Drislane, C.; Irvine, A.D. The role of filaggrin in atopic dermatitis and allergic disease. Ann. Allergy Asthma Immunol. 2020, 124, 36-43. [CrossRef] [PubMed] 
8. Thepen, T.; Langeveld-Wildschut, E.G.; Bihari, I.C.; van Wichen, D.F.; van Reijsen, F.C.; Mudde, G.C.; Bruijnzeel-Koomen, C.A. Biphasic response against aeroallergen in atopic dermatitis showing a switch from an initial TH2 response to a TH1 response in situ: An immunocytochemical study. J. Allergy Clin. Immunol. 1996, 97, 828-837. [CrossRef]

9. Pivarcsi, A.; Homey, B. Chemokine networks in atopic dermatitis: Traffic signals of disease. Curr. Allergy Asthma Rep. 2005, 5, 284-290. [CrossRef]

10. Salimi, M.; Barlow, J.L.; Saunders, S.P.; Xue, L.; Gutowska-Owsiak, D.; Wang, X.; Huang, L.C.; Johnson, D.; Scanlon, S.T.; McKenzie, A.N.; et al. A role for IL-25 and IL-33-driven type-2 innate lymphoid cells in atopic dermatitis. J. Exp. Med. 2013, 210, 2939-2950. [CrossRef]

11. Cosmi, L.; Maggi, L.; Mazzoni, A.; Liotta, F.; Annunziato, F. Biologicals targeting type 2 immunity: Lessons learned from asthma, chronic urticaria and atopic dermatitis. Eur. J. Immunol. 2019, 49, 1334-1343. [CrossRef]

12. Ho, A.W.; Kupper, T.S. T cells and the skin: From protective immunity to inflammatory skin disorders. Nat. Rev. Immunol. 2019, 19, 490-502. [CrossRef]

13. Brunner, P.M.; Guttman-Yassky, E.; Leung, D.Y. The immunology of atopic dermatitis and its reversibility with broad-spectrum and targeted therapies. J. Allergy Clin. Immunol. 2017, 139, S65-S76. [CrossRef]

14. Werfel, T.; Allam, J.P.; Biedermann, T.; Eyerich, K.; Gilles, S.; Guttman-Yassky, E.; Hoetzenecker, W.; Knol, E.; Simon, H.U.; Wollenberg, A.; et al. Cellular and molecular immunologic mechanisms in patients with atopic dermatitis. J. Allergy Clin. Immunol. 2016, 138, 336-349. [CrossRef]

15. Gittler, J.K.; Shemer, A.; Suárez-Fariñas, M.; Fuentes-Duculan, J.; Gulewicz, K.J.; Wang, C.Q.; Mitsui, H.; Cardinale, I.; de Guzman Strong, C.; Krueger, J.G.; et al. Progressive activation of $\mathrm{T}(\mathrm{H}) 2 / \mathrm{T}(\mathrm{H}) 22$ cytokines and selective epidermal proteins characterizes acute and chronic atopic dermatitis. J. Allergy Clin. Immunol. 2012, 130, 1344-1354. [CrossRef]

16. Renert-Yuval, Y.; Thyssen, J.P.; Bissonnette, R.; Bieber, T.; Kabashima, K.; Hijnen, D.; Guttman-Yassky, E. Biomarkers in atopic dermatitis-A review on behalf of the International Eczema Council. J. Allergy Clin. Immunol. 2021, 147, 1174-1190.e1. [CrossRef] [PubMed]

17. Czarnowicki, T.; He, H.; Krueger, J.G.; Guttman-Yassky, E. Atopic dermatitis endotypes and implications for targeted therapeutics. J. Allergy Clin. Immunol. 2019, 143, 1-11. [CrossRef] [PubMed]

18. Weidinger, S.; Novak, N. Atopic dermatitis. Lancet 2016, 387, 1109-1122. [CrossRef]

19. Yew, Y.W.; Thyssen, J.P.; Silverberg, J.I. A systematic review and meta-analysis of the regional and age-related differences in atopic dermatitis clinical characteristics. J. Am. Acad. Dermatol. 2019, 80, 390-401. [CrossRef]

20. Czarnowicki, T.; He, H.; Canter, T.; Han, J.; Lefferdink, R.; Erickson, T.; Rangel, S.; Kameyama, N.; Kim, H.J.; Pavel, A.B.; et al. Evolution of pathologic T-cell subsets in patients with atopic dermatitis from infancy to adulthood. J. Allergy Clin. Immunol. 2020, 145, 215-228. [CrossRef] [PubMed]

21. Esaki, H.; Czarnowicki, T.; Gonzalez, J.; Oliva, M.; Talasila, S.; Haugh, I.; Rodriguez, G.; Becker, L.; Krueger, J.G.; Guttman-Yassky, E.; et al. Accelerated T-cell activation and differentiation of polar subsets characterizes early atopic dermatitis development. $J$. Allergy Clin. Immunol. 2016, 138, 1473-1477.e5. [CrossRef]

22. Renert-Yuval, Y.; Del Duca, E.; Pavel, A.B.; Fang, M.; Lefferdink, R.; Wu, J.; Diaz, A.; Estrada, Y.D.; Canter, T.; Zhang, N.; et al. The molecular features of normal and atopic dermatitis skin in infants, children, adolescents, and adults. J. Allergy Clin. Immunol. 2021, 148, 148-163. [CrossRef]

23. Girolomoni, G.; de Bruin-Weller, M.; Aoki, V.; Kabashima, K.; Deleuran, M.; Puig, L.; Bansal, A.; Rossi, A.B. Nomenclature and clinical phenotypes of atopic dermatitis. Ther. Adv. Chronic Dis. 2021, 12, 1-20. [CrossRef] [PubMed]

24. Wollenberg, A.; Barbarot, S.; Bieber, T.; Christen-Zaech, S.; Deleuran, M.; Fink-Wagner, A.; Gieler, U.; Girolomoni, G.; Lau, S.; Muraro, A.; et al. Consensus-based European guidelines for treatment of atopic eczema (atopic dermatitis) in adults and children: Part I. J. Eur. Acad. Dermatol. Venereol. 2018, 32, 657-682. [CrossRef]

25. Wollenberg, A.; Barbarot, S.; Bieber, T.; Christen-Zaech, S.; Deleuran, M.; Fink-Wagner, A.; Gieler, U.; Girolomoni, G.; Lau, S.; Muraro, A.; et al. Consensus-based European guidelines for treatment of atopic eczema (atopic dermatitis) in adults and children: Part II. J. Eur. Acad. Dermatol. Venereol. 2018, 32, 850-878. [CrossRef] [PubMed]

26. Boguniewicz, M.; Fonacier, L.; Guttman-Yassky, E.; Ong, P.Y.; Silverberg, J.; Farrar, J.R. Atopic dermatitis yardstick: Practical recommendations for an evolving therapeutic landscape. Ann. Allergy Asthma Immunol. 2018, 120, 10-22.e2. [CrossRef] [PubMed]

27. Katoh, N.; Ohya, Y.; Ikeda, M.; Ebihara, T.; Katayama, I.; Saeki, H.; Shimojo, N.; Tanaka, A.; Nakahara, T.; Nagao, M.; et al. Clinical practice guidelines for the management of atopic dermatitis 2018. J. Dermatol. 2019, 46, 1053-1101. [CrossRef] [PubMed]

28. Oranje, A.P. Practical issues on interpretation of scoring atopic dermatitis: SCORAD Index, objective SCORAD, patient-oriented SCORAD and Three-Item Severity score. Curr. Probl. Dermatol. 2011, 41, 149-155.

29. Rook, A.; Wilkinson, D.S.; Ebling, F.J.G. Textbook of Dermatology, 2nd ed.; Blackwell Scientific Publications: Oxford, UK, 1972; Volume 1, p. 303.

30. Caputo, R.; Ackerman, A.B.; Sison-Torre, E.Q. Pediatric Dermatology and Dermatopathology; Lea \& Febiger: Philadelphia, PA, USA, 1990; Volume 1, p. 176.

31. Darsow, U.; Pfab, F.; Valet, M.; Huss-Marp, J.; Behrendt, H.; Ring, J.; Ständer, S. Pruritus and atopic dermatitis. Clin. Rev. Allergy Immunol. 2011, 41, 237-244. [CrossRef] [PubMed]

32. Albrecht, M.; Dittrich, A.M. Expression and function of histamine and its receptors in atopic dermatitis. Mol. Cell. Pediatr. 2015, 2, 16. [CrossRef] [PubMed] 
33. Ohsawa, Y.; Hirasawa, N. The role of histamine $\mathrm{H} 1$ and $\mathrm{H} 4$ receptors in atopic dermatitis: From basic research to clinical study. Allergol. Int. 2014, 63, 533-542. [CrossRef]

34. Thangam, E.B.; Jemima, E.A.; Singh, H.; Baig, M.S.; Khan, M.; Mathias, C.B.; Church, M.K.; Saluja, R. The Role of Histamine and Histamine Receptors in Mast Cell-Mediated Allergy and Inflammation: The Hunt for New Therapeutic Targets. Front. Immunol. 2018, 9, 1873. [CrossRef]

35. Herman, S.M.; Vender, R.B. Antihistamines in the treatment of dermatitis. J. Cutan. Med. Surg. 2003, 7, 467-473. [CrossRef] [PubMed]

36. van Zuuren, E.J.; Apfelbacher, C.J.; Fedorowicz, Z.; Jupiter, A.; Matterne, U.; Weisshaar, E. No high level evidence to support the use of oral $\mathrm{H} 1$ antihistamines as monotherapy for eczema: A summary of a Cochrane systematic review. Syst. Rev. $2014,3,25$. [CrossRef] [PubMed]

37. He, A.; Feldman, S.R.; Fleischer, A.B., Jr. An assessment of the use of antihistamines in the management of atopic dermatitis. J. Am. Acad. Dermatol. 2018, 79, 92-96. [CrossRef] [PubMed]

38. Hannuksela, M.; Kalimo, K.; Lammintausta, K.; Mattila, T.; Turjanmaa, K.; Varjonen, E.; Coulie, P.J. Dose ranging study: Cetirizine in the treatment of atopic dermatitis in adults. Ann. Allergy 1993, 70, 127-133.

39. Kawashima, M.; Tango, T.; Noguchi, T.; Inagi, M.; Nakagawa, H.; Harada, S. Addition of fexofenadine to a topical corticosteroid reduces the pruritus associated with atopic dermatitis in a 1-week randomized, multicentre, double-blind, placebo-controlled, parallel-group study. Br. J. Dermatol. 2003, 148, 1212-1221. [CrossRef]

40. Werfel, T.; Layton, G.; Yeadon, M.; Whitlock, L.; Osterloh, I.; Jimenez, P.; Liu, W.; Lynch, V.; Asher, A.; Tsianakas, A.; et al. Efficacy and safety of the histamine H4 receptor antagonist ZPL-3893787 in patients with atopic dermatitis. J. Allergy Clin. Immunol. 2019, 143, 1830-1837.e4. [CrossRef] [PubMed]

41. Kim, B.E.; Leung, D.Y.M. Significance of Skin Barrier Dysfunction in Atopic Dermatitis. Allergy Asthma Immunol. Res. 2018, 10, 207-215. [CrossRef] [PubMed]

42. Cork, M.J.; Danby, S.G.; Vasilopoulos, Y.; Hadgraft, J.; Lane, M.E.; Moustafa, M.; Guy, R.H.; Macgowan, A.L.; Tazi-Ahnini, R.; Ward, S.J. Epidermal barrier dysfunction in atopic dermatitis. J. Investig. Dermatol. 2009, 129, 1892-1908. [CrossRef]

43. van Zuuren, E.J.; Fedorowicz, Z.; Arents, B.W.M. Emollients and moisturizers for eczema: Abridged Cochrane systematic review including GRADE assessments. Br. J. Dermatol. 2017, 177, 1256-1271. [CrossRef] [PubMed]

44. Simpson, E.L.; Chalmers, J.R.; Hanifin, J.M.; Thomas, K.S.; Cork, M.J.; McLean, W.H.; Brown, S.J.; Chen, Z.; Chen, Y.; Williams, H.C. Emollient enhancement of the skin barrier from birth offers effective atopic dermatitis prevention. J. Allergy Clin. Immunol. 2014, 134, 818-823. [CrossRef] [PubMed]

45. Chalmers, J.R.; Haines, R.H.; Bradshaw, L.E.; Montgomery, A.A.; Thomas, K.S.; Brown, S.J.; Ridd, M.J.; Lawton, S.; Simpson, E.L.; Cork, M.J.; et al. Daily emollient during infancy for prevention of eczema: The BEEP randomised controlled trial. Lancet 2020, 395, 962-972. [CrossRef]

46. Hon, K.L.; Kung, J.S.C.; Ng, W.G.G.; Leung, T.F. Emollient treatment of atopic dermatitis: Latest evidence and clinical considerations. Drugs Context 2018, 7, 212530. [CrossRef] [PubMed]

47. Chalmers, J.R.; Axon, E.; Harvey, J.; Santer, M.; Ridd, M.J.; Lawton, S.; Langan, S.; Roberts, A.; Ahmed, A.; Muller, I.; et al. Different strategies for using topical corticosteroids in people with eczema. Cochrane Database Syst. Rev. 2019, 2019, CD013356. [CrossRef]

48. McAleer, M.A.; Jakasa, I.; Stefanovic, N.; McLean, W.H.I.; Kezic, S.; Irvine, A.D. Topical corticosteroids normalize both skin and systemic inflammatory markers in infant atopic dermatitis. Br. J. Dermatol. 2021, 185, 153-163. [CrossRef] [PubMed]

49. Eichenfield, L.F.; Tom, W.L.; Berger, T.G.; Krol, A.; Paller, A.S.; Schwarzenberger, K.; Bergman, J.N.; Chamlin, S.L.; Cohen, D.E.; Cooper, K.D.; et al. Guidelines of care for the management of atopic dermatitis: Section 2. Management and treatment of atopic dermatitis with topical therapies. J. Am. Acad. Dermatol. 2014, 71, 116-132. [CrossRef] [PubMed]

50. Wollenberg, A.; Reitamo, S.; Girolomoni, G.; Lahfa, M.; Ruzicka, T.; Healy, E.; Giannetti, A.; Bieber, T.; Vyas, J.; Deleuran, M.; et al. Proactive treatment of atopic dermatitis in adults with $0.1 \%$ tacrolimus ointment. Allergy 2008, 63, 742-750. [CrossRef]

51. Schmitt, J.; von Kobyletzki, L.; Svensson, A.; Apfelbacher, C. Efficacy and tolerability of proactive treatment with topical corticosteroids and calcineurin inhibitors for atopic eczema: Systematic review and meta-analysis of randomized controlled trials. Br. J. Dermatol. 2011, 164, 415-428. [CrossRef] [PubMed]

52. Siegfried, E.C.; Jaworski, J.C.; Kaiser, J.D.; Hebert, A.A. Systematic review of published trials: Long-term safety of topical corticosteroids and topical calcineurin inhibitors in pediatric patients with atopic dermatitis. BMC Pediatr. 2016, 16, 75. [CrossRef]

53. Broeders, J.A.; Ahmed Ali, U.; Fischer, G. Systematic review and meta-analysis of randomized clinical trials (RCTs) comparing topical calcineurin inhibitors with topical corticosteroids for atopic dermatitis: A 15-year experience. J. Am. Acad. Dermatol. 2016, 75, 410-419.e3. [CrossRef]

54. Byrd, A.L.; Belkaid, Y.; Segre, J.A. The human skin microbiome. Nat. Rev. Microbiol. 2018, 16, 143-155. [CrossRef] [PubMed]

55. Nakatsuji, T.; Chen, T.H.; Narala, S.; Chun, K.A.; Two, A.M.; Yun, T.; Shafiq, F.; Kotol, P.F.; Bouslimani, A.; Melnik, A.V.; et al. Antimicrobials from human skin commensal bacteria protect against Staphylococcus aureus and are deficient in atopic dermatitis. Sci. Transl. Med. 2017, 9, eaah4680. [CrossRef]

56. Byrd, A.L.; Deming, C.; Cassidy, S.K.B.; Harrison, O.J.; Ng, W.I.; Conlan, S.; NISC Comparative Sequencing Program; Belkaid, Y.; Segre, J.A.; Kong, H.H. Staphylococcus aureus and Staphylococcus epidermidis strain diversity underlying pediatric atopic dermatitis. Sci. Transl. Med. 2017, 9, eaal4651. [CrossRef] [PubMed] 
57. Gueniche, A.; Knaudt, B.; Schuck, E.; Volz, T.; Bastien, P.; Martin, R.; Röcken, M.; Breton, L.; Biedermann, T. Effects of nonpathogenic gram-negative bacterium Vitreoscilla filiformis lysate on atopic dermatitis: A prospective, randomized, doubleblind, placebo-controlled clinical study. Br. J. Dermatol. 2008, 159, 1357-1363. [CrossRef]

58. Volz, T.; Skabytska, Y.; Guenova, E.; Chen, K.M.; Frick, J.S.; Kirschning, C.J.; Kaesler, S.; Röcken, M.; Biedermann, T. Nonpathogenic bacteria alleviating atopic dermatitis inflammation induce IL-10-producing dendritic cells and regulatory Tr1 cells. J. Investig. Dermatol. 2014, 134, 96-104. [CrossRef] [PubMed]

59. Harkins, C.P.; McAleer, M.A.; Bennett, D.; McHugh, M.; Fleury, O.M.; Pettigrew, K.A.; Oravcová, K.; Parkhill, J.; Proby, C.M.; Dawe, R.S.; et al. The widespread use of topical antimicrobials enriches for resistance in Staphylococcus aureus isolated from patients with atopic dermatitis. Br. J. Dermatol. 2018, 179, 951-958. [CrossRef] [PubMed]

60. Hajikhani, B.; Goudarzi, M.; Kakavandi, S.; Amini, S.; Zamani, S.; van Belkum, A.; Goudarzi, H.; Dadashi, M. The global prevalence of fusidic acid resistance in clinical isolates of Staphylococcus aureus: A systematic review and meta-analysis. Antimicrob. Resist. Infect. Control 2021, 10, 75. [CrossRef] [PubMed]

61. Nakatsuji, T.; Gallo, R.L. The role of the skin microbiome in atopic dermatitis. Ann. Allergy Asthma Immunol. 2019, 122, 263-269. [CrossRef]

62. Simpson, E.L.; Bruin-Weller, M.; Flohr, C.; Ardern-Jones, M.R.; Barbarot, S.; Deleuran, M.; Bieber, T.; Vestergaard, C.; Brown, S.J.; Cork, M.J.; et al. When does atopic dermatitis warrant systemic therapy? Recommendations from an expert panel of the International Eczema Council. J. Am. Acad. Dermatol. 2017, 77, 623-633. [CrossRef]

63. Schmitt, J.; Schmitt, N.; Meurer, M. Cyclosporin in the treatment of patients with atopic eczema-A systematic review and meta-analysis. J. Eur. Acad. Dermatol. Venereol. 2007, 21, 606-619. [CrossRef]

64. Hijnen, D.J.; ten Berge, O.; Timmer-de Mik, L.; Bruijnzeel-Koomen, C.A.; de Bruin-Weller, M.S. Efficacy and safety of long-term treatment with cyclosporin A for atopic dermatitis. J. Eur. Acad. Dermatol. Venereol. 2007, 21, 85-89. [CrossRef] [PubMed]

65. Berth-Jones, J.; Takwale, A.; Tan, E.; Barclay, G.; Agarwal, S.; Ahmed, I.; Hotchkiss, K.; Graham-Brown, R.A. Azathioprine in severe adult atopic dermatitis: A double-blind, placebo-controlled, crossover trial. Br. J. Dermatol. 2002, 147, 324-330. [CrossRef] [PubMed]

66. Thomsen, S.F.; Karlsmark, T.; Clemmensen, K.K.; Graversgaard, C.; Ibler, K.S.; Jemec, G.B.; Agner, T. Outcome of treatment with azathioprine in severe atopic dermatitis: A 5-year retrospective study of adult outpatients. Br. J. Dermatol. 2015, 172, 1122-1124. [CrossRef] [PubMed]

67. Schram, M.E.; Roekevisch, E.; Leeflang, M.M.; Bos, J.D.; Schmitt, J.; Spuls, P.I. A randomized trial of methotrexate versus azathioprine for severe atopic eczema. J. Allergy Clin. Immunol. 2011, 128, 353-359. [CrossRef]

68. Haeck, I.M.; Knol, M.J.; Ten Berge, O.; van Velsen, S.G.; de Bruin-Weller, M.S.; Bruijnzeel-Koomen, C.A. Enteric-coated mycophenolate sodium versus cyclosporin A as long-term treatment in adult patients with severe atopic dermatitis: A randomized controlled trial. J. Am. Acad. Dermatol. 2011, 64, 1074-1084. [CrossRef]

69. Grundmann-Kollmann, M.; Podda, M.; Ochsendorf, F.; Boehncke, W.H.; Kaufmann, R.; Zollner, T.M. Mycophenolate mofetil is effective in the treatment of atopic dermatitis. Arch. Dermatol. 2001, 137, 870-873.

70. Puar, N.; Chovatiya, R.; Paller, A.S. New treatments in atopic dermatitis. Ann. Allergy Asthma Immunol. 2021, 126, 21-31. [CrossRef]

71. Agache, I.; Cojanu, C.; Laculiceanu, A.; Rogozea, L. Critical Points on the Use of Biologicals in Allergic Diseases and Asthma. Allergy Asthma Immunol. Res. 2020, 12, 24-41. [CrossRef]

72. Renert-Yuval, Y.; Guttman-Yassky, E. New treatments for atopic dermatitis targeting beyond IL-4/IL-13 cytokines. Ann. Allergy Asthma Immunol. 2020, 124, 28-35. [CrossRef]

73. Simpson, E.L.; Bieber, T.; Guttman-Yassky, E.; Beck, L.A.; Blauvelt, A.; Cork, M.J.; Silverberg, J.I.; Deleuran, M.; Kataoka, Y.; Lacour, J.P.; et al. Two Phase 3 Trials of Dupilumab versus Placebo in Atopic Dermatitis. N. Engl. J. Med. 2016, 375, $2335-2348$. [CrossRef] [PubMed]

74. Tabata, Y.; Hershey, G.K.K. IL-13 receptor isoforms: Breaking through the complexity. Curr. Allergy Asthma Rep. 2007, 7, 338-345. [CrossRef]

75. Junttila, I.S. Tuning the Cytokine Responses: An Update on Interleukin (IL)-4 and IL-13 Receptor Complexes. Front. Immunol. 2018, 9, 888. [CrossRef] [PubMed]

76. Hamilton, J.D.; Suárez-Fariñas, M.; Dhingra, N.; Cardinale, I.; Li, X.; Kostic, A.; Ming, J.E.; Radin, A.R.; Krueger, J.G.; Graham, N.; et al. Dupilumab improves the molecular signature in skin of patients with moderate-to-severe atopic dermatitis. J. Allergy Clin. Immunol. 2014, 134, 1293-1300. [CrossRef]

77. U.S. Food and Drug Administration (FDA). Available online: https://www.fda.gov/news-events/press-announcements/fdaapproves-new-eczema-drug-dupixent (accessed on 25 July 2021).

78. Senner, S.; Seegräber, M.; Frey, S.; Kendziora, B.; Eicher, L.; Wollenberg, A. Dupilumab for the treatment of adolescents with atopic dermatitis. Expert Rev. Clin. Immunol. 2020, 16, 641-650. [CrossRef] [PubMed]

79. European Medicines Agency. Available online: https://www.ema.europa.eu/en/medicines/human/EPAR/dupixent (accessed on 25 July 2021).

80. Sanofi. Available online: https:/ /www.sanofi.com/en/media-room/press-releases/2020/2020-05-26-17-40-00 (accessed on 25 July 2021). 
81. Gooderham, M.J.; Hong, H.C.; Eshtiaghi, P.; Papp, K.A. Dupilumab: A review of its use in the treatment of atopic dermatitis. J. Am. Acad. Dermatol. 2018, 78 (Suppl. S1), S28-S36. [CrossRef]

82. Simpson, E.L.; Paller, A.S.; Siegfried, E.C.; Boguniewicz, M.; Sher, L.; Gooderham, M.J.; Beck, L.A.; Guttman-Yassky, E.; Pariser, D.; Blauvelt, A.; et al. Efficacy and Safety of Dupilumab in Adolescents with Uncontrolled Moderate to Severe Atopic Dermatitis: A Phase 3 Randomized Clinical Trial. JAMA Dermatol. 2020, 156, 44-56. [CrossRef]

83. Paller, A.S.; Siegfried, E.C.; Thaçi, D.; Wollenberg, A.; Cork, M.J.; Arkwright, P.D.; Gooderham, M.; Beck, L.A.; Boguniewicz, M.; Sher, L.; et al. Efficacy and safety of dupilumab with concomitant topical corticosteroids in children 6 to 11 years old with severe atopic dermatitis: A randomized, double-blinded, placebo-controlled phase 3 trial. J. Am. Acad. Dermatol. 2020, 83, 1282-1293. [CrossRef]

84. de Bruin-Weller, M.; Thaçi, D.; Smith, C.H.; Reich, K.; Cork, M.J.; Radin, A.; Zhang, Q.; Akinlade, B.; Gadkari, A.; Eckert, L.; et al. Dupilumab with concomitant topical corticosteroid treatment in adults with atopic dermatitis with an inadequate response or intolerance to ciclosporin A or when this treatment is medically inadvisable: A placebo-controlled, randomized phase III clinical trial (LIBERTY AD CAFÉ). Br. J. Dermatol. 2018, 178, 1083-1101.

85. Deleuran, M.; Thaçi, D.; Beck, L.A.; de Bruin-Weller, M.; Blauvelt, A.; Forman, S.; Bissonnette, R.; Reich, K.; Soong, W.; Hussain, I.; et al. Dupilumab shows long-term safety and efficacy in patients with moderate to severe atopic dermatitis enrolled in a phase 3 open-label extension study. J. Am. Acad. Dermatol. 2020, 82, 377-388. [CrossRef]

86. Nettis, E.; Bonzano, L.; Patella, V.; Detoraki, A.; Trerotoli, P.; Lombardo, C.; Italian DADReL (Dupilumab Atopic Dermatitis in Real Life) Study Group. Dupilumab-Associated Conjunctivitis in Patients with Atopic Dermatitis: A Multicenter Real-Life Experience. J. Investig. Allergol. Clin. Immunol. 2020, 30, 201-204. [CrossRef] [PubMed]

87. Halling, A.S.; Loft, N.; Silverberg, J.I.; Guttman-Yassky, E.; Thyssen, J.P. Real-world evidence of dupilumab efficacy and risk of adverse events: A systematic review and meta-analysis. J. Am. Acad. Dermatol. 2021, 84, 139-147. [CrossRef] [PubMed]

88. Akinlade, B.; Guttman-Yassky, E.; de Bruin-Weller, M.; Simpson, E.L.; Blauvelt, A.; Cork, M.J.; Prens, E.; Asbell, P.; Akpek, E.; Corren, J.; et al. Conjunctivitis in dupilumab clinical trials. Br. J. Dermatol. 2019, 181, 459-473. [CrossRef]

89. Bansal, A.; Simpson, E.L.; Paller, A.S.; Siegfried, E.C.; Blauvelt, A.; de Bruin-Weller, M.; Corren, J.; Sher, L.; Guttman-Yassky, E.; Chen, Z.; et al. Conjunctivitis in Dupilumab Clinical Trials for Adolescents with Atopic Dermatitis or Asthma. Am. J. Clin. Dermatol. 2021, 22, 101-115. [CrossRef]

90. Popiela, M.Z.; Barbara, R.; Turnbull, A.M.J.; Corden, E.; Martinez-Falero, B.S.; O’Driscoll, D.; Ardern-Jones, M.R.; Hossain, P.N. Dupilumab-associated ocular surface disease: Presentation, management and long-term sequelae. Eye 2021. [CrossRef] [PubMed]

91. Cork, M.J.; Thaçi, D.; Eichenfield, L.F.; Arkwright, P.D.; Sun, X.; Chen, Z.; Akinlade, B.; Boklage, S.; Guillemin, I.; Kosloski, M.P.; et al. Dupilumab provides favourable long-term safety and efficacy in children aged $\geq 6$ to $<12$ years with uncontrolled severe atopic dermatitis: Results from an open-label phase IIa study and subsequent phase III open-label extension study. Br. J. Dermatol. 2021, 184, 857-870.

92. Agache, I.; Song, Y.; Posso, M.; Alonso-Coello, P.; Rocha, C.; Solà, I.; Beltran, J.; Akdis, C.A.; Akdis, M.; Brockow, K.; et al. Efficacy and safety of dupilumab for moderate-to-severe atopic dermatitis: A systematic review for the EAACI biologicals guidelines. Allergy 2021, 76, 45-58. [CrossRef]

93. Drucker, A.M.; Ellis, A.G.; Bohdanowicz, M.; Mashayekhi, S.; Yiu, Z.Z.N.; Rochwerg, B.; Di Giorgio, S.; Arents, B.W.M.; Burton, T.; Spuls, P.I.; et al. Systemic Immunomodulatory Treatments for Patients with Atopic Dermatitis: A Systematic Review and Network Meta-analysis. JAMA Dermatol. 2020, 156, 659-667. [CrossRef]

94. Spekhorst, L.S.; Ariëns, L.F.M.; van der Schaft, J.; Bakker, D.S.; Kamsteeg, M.; Oosting, A.J.; de Ridder, I.; Sloeserwij, A.; Romeijn, G.L.E.; de Graaf, M.; et al. Two-year drug survival of dupilumab in a large cohort of difficult-to-treat adult atopic dermatitis patients compared to cyclosporine A and methotrexate: Results from the BioDay registry. Allergy 2020, 75, 2376-2379. [CrossRef]

95. Dal Bello, G.; Maurelli, M.; Schena, D.; Girolomoni, G.; Gisondi, P. Drug survival of dupilumab compared to cyclosporin in moderate-to-severe atopic dermatitis patients. Dermatol. Ther. 2020, 33, e13979. [CrossRef]

96. Paller, A.S.; Kabashima, K.; Bieber, T. Therapeutic pipeline for atopic dermatitis: End of the drought? J. Allergy Clin. Immunol. 2017, 140, 633-643. [CrossRef] [PubMed]

97. Ratchataswan, T.; Banzon, T.M.; Thyssen, J.P.; Weidinger, S.; Guttman-Yassky, E.; Phipatanakul, W. Biologics for Treatment of Atopic Dermatitis: Current Status and Future Prospect. J. Allergy Clin. Immunol. Pract. 2021, 9, 1053-1065. [CrossRef] [PubMed]

98. Zhou, S.; Qi, F.; Gong, Y.; Zhang, J.; Zhu, B. Biological Therapies for Atopic Dermatitis: A Systematic Review. Dermatology 2021, 237, 542-552. [CrossRef] [PubMed]

99. Wollenberg, A.; Howell, M.D.; Guttman-Yassky, E.; Silverberg, J.I.; Kell, C.; Ranade, K.; Moate, R.; van der Merwe, R. Treatment of atopic dermatitis with tralokinumab, an anti-IL-13 mAb. J. Allergy Clin. Immunol. 2019, 143, 135-141. [CrossRef] [PubMed]

100. Wollenberg, A.; Blauvelt, A.; Guttman-Yassky, E.; Worm, M.; Lynde, C.; Lacour, J.P.; Spelman, L.; Katoh, N.; Saeki, H.; Poulin, Y.; et al. Tralokinumab for moderate-to-severe atopic dermatitis: Results from two 52-week, randomized, double-blind, multicentre, placebo-controlled phase III trials (ECZTRA 1 and ECZTRA 2). Br. J. Dermatol. 2021, 184, 437-449. [CrossRef]

101. Guttman-Yassky, E.; Blauvelt, A.; Eichenfield, L.F.; Paller, A.S.; Armstrong, A.W.; Drew, J.; Gopalan, R.; Simpson, E.L. Efficacy and Safety of Lebrikizumab, a High-Affinity Interleukin 13 Inhibitor, in Adults with Moderate to Severe Atopic Dermatitis: A Phase 2b Randomized Clinical Trial. JAMA Dermatol. 2020, 156, 411-420. [CrossRef]

102. Guttman-Yassky, E.; Brunner, P.M.; Neumann, A.U.; Khattri, S.; Pavel, A.B.; Malik, K.; Singer, G.K.; Baum, D.; Gilleaudeau, P.; Sullivan-Whalen, M.; et al. Efficacy and safety of fezakinumab (an IL-22 monoclonal antibody) in adults with moderate-to-severe 
atopic dermatitis inadequately controlled by conventional treatments: A randomized, double-blind, phase 2a trial. J. Am. Acad. Dermatol. 2018, 78, 872-881.e6. [CrossRef] [PubMed]

103. Brunner, P.M.; Pavel, A.B.; Khattri, S.; Leonard, A.; Malik, K.; Rose, S.; Jim On, S.; Vekaria, A.S.; Traidl-Hoffmann, C.; Singer, G.K.; et al. Baseline IL-22 expression in patients with atopic dermatitis stratifies tissue responses to fezakinumab. J. Allergy Clin. Immunol. 2019, 143, 142-154. [CrossRef] [PubMed]

104. Simpson, E.L.; Parnes, J.R.; She, D.; Crouch, S.; Rees, W.; Mo, M.; van der Merwe, R. Tezepelumab, an anti-thymic stromal lymphopoietin monoclonal antibody, in the treatment of moderate to severe atopic dermatitis: A randomized phase 2a clinical trial. J. Am. Acad. Dermatol. 2019, 80, 1013-1021. [CrossRef]

105. Chen, Y.L.; Gutowska-Owsiak, D.; Hardman, C.S.; Westmoreland, M.; MacKenzie, T.; Cifuentes, L.; Waithe, D.; Lloyd-Lavery, A.; Marquette, A.; Londei, M.; et al. Proof-of-concept clinical trial of etokimab shows a key role for IL-33 in atopic dermatitis pathogenesis. Sci. Transl. Med. 2019, 11, eaax2945. [CrossRef]

106. Ungar, B.; Pavel, A.B.; Li, R.; Kimmel, G.; Nia, J.; Hashim, P.; Kim, H.J.; Chima, M.; Vekaria, A.S.; Estrada, Y.; et al. Phase 2 randomized, double-blind study of IL-17 targeting with secukinumab in atopic dermatitis. J. Allergy Clin. Immunol. 2021, 147, 394-397. [CrossRef] [PubMed]

107. Vandeghinste, N.; Klattig, J.; Jagerschmidt, C.; Lavazais, S.; Marsais, F.; Haas, J.D.; Auberval, M.; Lauffer, F.; Moran, T.; Ongenaert, M.; et al. Neutralization of IL-17C Reduces Skin Inflammation in Mouse Models of Psoriasis and Atopic Dermatitis. J. Investig. Dermatol. 2018, 138, 1555-1563. [CrossRef] [PubMed]

108. Guttman-Yassky, E.; Krueger, J.G. IL-17C: A Unique Epithelial Cytokine with Potential for Targeting across the Spectrum of Atopic Dermatitis and Psoriasis. J. Investig. Dermatol. 2018, 138, 1467-1469. [CrossRef] [PubMed]

109. Guttman-Yassky, E.; Pavel, A.B.; Zhou, L.; Estrada, Y.D.; Zhang, N.; Xu, H.; Peng, X.; Wen, H.C.; Govas, P.; Gudi, G.; et al. GBR 830, an anti-OX40, improves skin gene signatures and clinical scores in patients with atopic dermatitis. J. Allergy Clin. Immunol. 2019, 144, 482-493.e7. [CrossRef]

110. Furue, M.; Furue, M. OX40L-OX40 Signaling in Atopic Dermatitis. J. Clin. Med. 2021, 10, 2578. [CrossRef] [PubMed]

111. Nakagawa, H.; Iizuka, H.; Nemoto, O.; Shimabe, M.; Furukawa, Y.; Kikuta, N.; Ootaki, K. Safety, tolerability and efficacy of repeated intravenous infusions of KHK4083, a fully human anti-OX40 monoclonal antibody, in Japanese patients with moderate to severe atopic dermatitis. J. Dermatol. Sci. 2020, 99, 82-89. [CrossRef]

112. Ruzicka, T.; Hanifin, J.M.; Furue, M.; Pulka, G.; Mlynarczyk, I.; Wollenberg, A.; Galus, R.; Etoh, T.; Mihara, R.; Yoshida, H.; et al. Anti-Interleukin-31 Receptor A Antibody for Atopic Dermatitis. N. Engl. J. Med. 2017, 376, 826-835. [CrossRef]

113. Kabashima, K.; Furue, M.; Hanifin, J.M.; Pulka, G.; Wollenberg, A.; Galus, R.; Etoh, T.; Mihara, R.; Nakano, M.; Ruzicka, T. Nemolizumab in patients with moderate-to-severe atopic dermatitis: Randomized, phase II, long-term extension study. J. Allergy Clin. Immunol. 2018, 142, 1121-1130.e7. [CrossRef]

114. Silverberg, J.I.; Pinter, A.; Pulka, G.; Poulin, Y.; Bouaziz, J.D.; Wollenberg, A.; Murrell, D.F.; Alexis, A.; Lindsey, L.; Ahmad, F.; et al. Phase $2 \mathrm{~B}$ randomized study of nemolizumab in adults with moderate-to-severe atopic dermatitis and severe pruritus. J. Allergy Clin. Immunol. 2020, 145, 173-182. [CrossRef]

115. Kabashima, K.; Matsumura, T.; Komazaki, H.; Kawashima, M.; Nemolizumab-JP01 Study Group. Trial of Nemolizumab and Topical Agents for Atopic Dermatitis with Pruritus. N. Engl. J. Med. 2020, 383, 141-150. [CrossRef]

116. Paller, A.S.; Tom, W.L.; Lebwohl, M.G.; Blumenthal, R.L.; Boguniewicz, M.; Call, R.S.; Eichenfield, L.F.; Forsha, D.W.; Rees, W.C.; Simpson, E.L.; et al. Efficacy and safety of crisaborole ointment, a novel, nonsteroidal phosphodiesterase 4 (PDE4) inhibitor for the topical treatment of atopic dermatitis (AD) in children and adults. J. Am. Acad. Dermatol. 2016, 75, 494-503.e6. [CrossRef]

117. Eichenfield, L.F.; Call, R.S.; Forsha, D.W.; Fowler, J., Jr.; Hebert, A.A.; Spellman, M.; Gold, L.F.S.; Van Syoc, M.; Zane, L.T.; Tschen, E. Long-term safety of crisaborole ointment $2 \%$ in children and adults with mild to moderate atopic dermatitis. J. Am. Acad. Dermatol. 2017, 77, 641-649.e5. [CrossRef]

118. Bissonnette, R.; Pavel, A.B.; Diaz, A.; Werth, J.L.; Zang, C.; Vranic, I.; Purohit, V.S.; Zielinski, M.A.; Vlahos, B.; Estrada, Y.D.; et al. Crisaborole and atopic dermatitis skin biomarkers: An intrapatient randomized trial. J. Allergy Clin. Immunol. 2019, 144, 1274-1289. [CrossRef]

119. Solimani, F.; Meier, K.; Ghoreschi, K. Emerging Topical and Systemic JAK Inhibitors in Dermatology. Front. Immunol. 2019, 10, 2847. [CrossRef]

120. Bieber, T. Leveraging the nice face of Janus kinase inhibition-ruxolitinib cream in atopic dermatitis. J. Allergy Clin. Immunol. 2020, 145, 489-490. [CrossRef]

121. Cartron, A.M.; Nguyen, T.H.; Roh, Y.S.; Kwatra, M.M.; Kwatra, S.G. Janus kinase inhibitors for atopic dermatitis: A promising treatment modality. Clin. Exp. Dermatol. 2021, 46, 820-824. [CrossRef] [PubMed]

122. Li, C.; Sun, X.; Zhao, K.; Meng, F.; Li, L.; Mu, Z.; Han, X. Efficacy and Safety of Janus Kinase Inhibitors for the Treatment of Atopic Dermatitis: A Systematic Review and Meta-Analysis. Dermatology 2021, 27, 1-11.

123. Nakagawa, H.; Nemoto, O.; Igarashi, A.; Saeki, H.; Oda, M.; Kabashima, K.; Nagata, T. Phase 2 clinical study of delgocitinib ointment in pediatric patients with atopic dermatitis. J. Allergy Clin. Immunol. 2019, 144, 1575-1583. [CrossRef] [PubMed]

124. Nakagawa, H.; Nemoto, O.; Igarashi, A.; Saeki, H.; Kaino, H.; Nagata, T. Delgocitinib ointment, a topical Janus kinase inhibitor, in adult patients with moderate to severe atopic dermatitis: A phase 3, randomized, double-blind, vehicle-controlled study and an open-label, long-term extension study. J. Am. Acad. Dermatol. 2020, 82, 823-831. [CrossRef] 
125. Nakagawa, H.; Nemoto, O.; Igarashi, A.; Saeki, H.; Murata, R.; Kaino, H.; Nagata, T. Long-term safety and efficacy of delgocitinib ointment, a topical Janus kinase inhibitor, in adult patients with atopic dermatitis. J. Dermatol. 2020, 47, 114-120. [CrossRef]

126. Dhillon, S. Delgocitinib: First Approval. Drugs 2020, 80, 609-615. [CrossRef] [PubMed]

127. Kim, B.S.; Howell, M.D.; Sun, K.; Papp, K.; Nasir, A.; Kuligowski, M.E.; INCB 18424-206 Study Investigators. Treatment of atopic dermatitis with ruxolitinib cream (JAK1/JAK2 inhibitor) or triamcinolone cream. J. Allergy Clin. Immunol. 2020, 145, 572-582. [CrossRef] [PubMed]

128. Kim, B.S.; Sun, K.; Papp, K.; Venturanza, M.; Nasir, A.; Kuligowski, M.E. Effects of ruxolitinib cream on pruritus and quality of life in atopic dermatitis: Results from a phase 2, randomized, dose-ranging, vehicle- and active-controlled study. J. Am. Acad. Dermatol. 2020, 82, 1305-1313. [CrossRef] [PubMed]

129. Bissonnette, R.; Papp, K.A.; Poulin, Y.; Gooderham, M.; Raman, M.; Mallbris, L.; Wang, C.; Purohit, V.; Mamolo, C.; Papacharalambous, J.; et al. Topical tofacitinib for atopic dermatitis: A phase Ila randomized trial. Br. J. Dermatol. 2016, 175, 902-911. [CrossRef]

130. Simpson, E.L.; Lacour, J.P.; Spelman, L.; Galimberti, R.; Eichenfield, L.F.; Bissonnette, R.; King, B.A.; Thyssen, J.P.; Silverberg, J.I.; Bieber, T.; et al. Baricitinib in patients with moderate-to-severe atopic dermatitis and inadequate response to topical corticosteroids: Results from two randomized monotherapy phase III trials. Br. J. Dermatol. 2020, 183, 242-255. [CrossRef]

131. Silverberg, J.I.; Simpson, E.L.; Wollenberg, A.; Bissonnette, R.; Kabashima, K.; DeLozier, A.M.; Sun, L.; Cardillo, T.; Nunes, F.P.; Reich, K. Long-term Efficacy of Baricitinib in Adults with Moderate to Severe Atopic Dermatitis Who Were Treatment Responders or Partial Responders: An Extension Study of 2 Randomized Clinical Trials. JAMA Dermatol. 2021, 12, e211273.

132. Reich, K.; Kabashima, K.; Peris, K.; Silverberg, J.I.; Eichenfield, L.F.; Bieber, T.; Kaszuba, A.; Kolodsick, J.; Yang, F.E.; Gamalo, M.; et al. Efficacy and Safety of Baricitinib Combined with Topical Corticosteroids for Treatment of Moderate to Severe Atopic Dermatitis: A Randomized Clinical Trial. JAMA Dermatol. 2020, 156, 1333-1343. [CrossRef]

133. Siegels, D.; Heratizadeh, A.; Abraham, S.; Binnmyr, J.; Brockow, K.; Irvine, A.D.; Halken, S.; Mortz, C.G.; Flohr, C.; SchmidGrendelmeier, P.; et al. Systemic treatments in the management of atopic dermatitis: A systematic review and meta-analysis. Allergy 2021, 76, 1053-1076. [CrossRef] [PubMed]

134. Ferreira, S.; Guttman-Yassky, E.; Torres, T. Selective JAK1 Inhibitors for the Treatment of Atopic Dermatitis: Focus on Upadacitinib and Abrocitinib. Am. J. Clin. Dermatol. 2020, 21, 783-798. [CrossRef]

135. Reich, K.; Teixeira, H.D.; de Bruin-Weller, M.; Bieber, T.; Soong, W.; Kabashima, K.; Werfel, T.; Zeng, J.; Huang, X.; Hu, X.; et al. Safety and efficacy of upadacitinib in combination with topical corticosteroids in adolescents and adults with moderate-to-severe atopic dermatitis (AD Up): Results from a randomised, double-blind, placebo-controlled, phase 3 trial. Lancet 2021, 397, $2169-2181$. [CrossRef]

136. Guttman-Yassky, E.; Thaçi, D.; Pangan, A.L.; Hong, H.C.; Papp, K.A.; Reich, K.; Beck, L.A.; Mohamed, M.F.; Othman, A.A.; Anderson, J.K.; et al. Upadacitinib in adults with moderate to severe atopic dermatitis: 16-week results from a randomized, placebo-controlled trial. J. Allergy Clin. Immunol. 2020, 145, 877-884. [CrossRef] [PubMed]

137. Bieber, T.; Simpson, E.L.; Silverberg, J.I.; Thaçi, D.; Paul, C.; Pink, A.E.; Kataoka, Y.; Chu, C.Y.; DiBonaventura, M.; Rojo, R.; et al. Abrocitinib versus Placebo or Dupilumab for Atopic Dermatitis. N. Engl. J. Med. 2021, 384, 1101-1112. [CrossRef] [PubMed]

138. Simpson, E.L.; Sinclair, R.; Forman, S.; Wollenberg, A.; Aschoff, R.; Cork, M.; Bieber, T.; Thyssen, J.P.; Yosipovitch, G.; Flohr, C.; et al. Efficacy and safety of abrocitinib in adults and adolescents with moderate-to-severe atopic dermatitis (JADE MONO-1): A multicentre, double-blind, randomised, placebo-controlled, phase 3 trial. Lancet 2020, 396, 255-266. [CrossRef]

139. Bissonnette, R.; Maari, C.; Forman, S.; Bhatia, N.; Lee, M.; Fowler, J.; Tyring, S.; Pariser, D.; Sofen, H.; Dhawan, S.; et al. The oral Janus kinase/spleen tyrosine kinase inhibitor ASN002 demonstrates efficacy and improves associated systemic inflammation in patients with moderate-to-severe atopic dermatitis: Results from a randomized double-blind placebo-controlled study. Br. J. Dermatol. 2019, 181, 733-742. [CrossRef] [PubMed]

140. Pavel, A.B.; Song, T.; Kim, H.J.; Del Duca, E.; Krueger, J.G.; Dubin, C.; Peng, X.; Xu, H.; Zhang, N.; Estrada, Y.D.; et al. Oral Janus kinase/SYK inhibition (ASN002) suppresses inflammation and improves epidermal barrier markers in patients with atopic dermatitis. J. Allergy Clin. Immunol. 2019, 144, 1011-1024. [CrossRef] [PubMed] 